\title{
The Effect of Liquidity, Leverage, and Profitability on Dividend Policy
}

\author{
Rona Tumiur Mauli Carolin Simorangkir ${ }^{1}$ \\ \{rona_caroline@mercubuana.ac.id ${ }^{1}$ \} \\ Universitas Mercu Buana, Indonesia
}

\begin{abstract}
Dividend are payments made by a corporate to shareholder members which is depend on the dividend policy of each company. The objective of this research is to analyze the influence of cash ratio, debt to equity ratio and return on asset to dividend policy from sample of companies. The population of this research is manufacture companies which listed in Bursa Efek Indonesia (BEI), there is 24 companies. Research sample using purposive sampling of companies for periode ended $2012-2016$. Analyzed by using the two tail linear regression method. The result show, debt to equity ratio and return on asset had a positive and significant effect to dividend policy. It proved by significant $t$ value lower than $5 \%$ significances.
\end{abstract}

Keywords: Dividend Policy, Cash Ratio, Debt to Equity Ratio (DER) and Return On Asset (ROA).

\section{Introduction}

According to kompas.com, Freeport Indonesia is not distributing dividends for the umpteenth time. Management of PT. Freeport Indonesia said that the mining company did not provide dividend revenue sharing to its shareholders because of negative cash flow so it was necessary to borrow funds from Freeport Mc Mo Ran for operations and investment commitments and also focus on underground mining investments that require large investments worth 15 billion US dollars. Thus, the policy of not giving dividends is the third year for the government to hold back thirst for the proceeds of Freeport dividends. Last year in 2011, the government still pocketed dividends of US \$ 202 million or Rp. 1.76 trillion. Even though it does not provide dividends, Freeport claims that it continues to make a positive contribution to the Government of Indonesia in the form of paying gold, copper and silver royalties worth 118 million US dollars, as well as paying taxes and non-taxes worth 421 million US dollars. Shares in PT. Freeport Indonesia is owned by Freeport Mc Mo Ran with a portion of 90.64 percent of the shares. Meanwhile, Indonesia only has 9.36 percent shares.

Dividend policy concerns the issue of profits earned into the rights of shareholders. The dividend payment policy has an influence on shareholders and for companies that will pay dividends. From the case of Freeport Indonesia, it did not distribute dividends in the 2014 performance year because the profits earned were invested in underground mining. With no dividends being deposited with the indonesian government, this has resulted in a reduction in income to the indonesian state revenue and expenditure budget. Freeport indonesia does not distribute dividends because the cash flow position is negative in the current year so it is necessary to borrow funds from Freeport McMoRan for operational and investment 
commitments. According to Darma \& Segoro (2014); Gumanti, (2013); Mahardika \& Mawardi (2016) and Minanari (2018) and states that "Dividends are cash flows paid to shareholders, the large ratio of cash dividend payments to shareholders is shown through Dividend Payout Ratio (DPR) $(1,2)(3,4)$

According to Nurhayati (2008); Hasibuan (2012); and Sari \& Andini (2016) explained that dividend policy determines the distribution of profits between payments to shareholders and re-investment of the company. According to the form of payment, dividends can be divided into two forms, namely Cash Dividend (cash dividend / cash dividend) and stock dividend (stock dividend). Cash dividends are dividends paid in cash. While the stock dividend is a dividend paid as the additional number of ordinary shares to the shareholders $(5)(6)(7)$

So far, research related to dividend policy or Dividend Payout Ratio (DPR) has been carried out. That financial ratios such as profitability ratios, liquidity ratios, and solvency ratios or financial leverage can be considered in dividend policy. By using different research objects, this study will review the effect of financial ratios on dividend policy or Dividend Payout Ratio (DPR). But in this study it is proxied by the variables Cash Ratio (CR), Debt to Equity Ratio (DER), and Return On Assets (ROA). To clarify and analyze the problem of dividend policy or Dividend Payout Ratio (DPR) and see the relationship with financial ratios in the company.

\section{Research methods}

The research method is causal research. This causal study aims to test hypotheses about the effect of one or several variables on several other variables, which variables in this study include the independent variables and the dependent variable. Independent variables include cash ratio, Debt To Equity Ratio (DER), and Return On Assets (ROA). The dependent variable in this study is the Dividend Payout Ratio (DPR).

\section{Results and Discussion}

The results of the descriptive statistics of the independent variables (X1) are cash ratios with the number of samples $(\mathrm{N})$ there are 120 samples, the minimum cash ratio in the amount of 0.004140 for PT. Gudang Garam Tbk in 2012. The maximum value of 478,963588 for PT. Lion Metal Work Tbk in 2012. The average value is 90.54656305 and the standard deviation is 111.966580484 .

Based on the processed data for 2012-2016 regarding the variable Debt to Equity Ratio (DER) (X2) with the number of samples (N) there are 120 samples. From this study, the minimum value for the variable Debt to Equity Ratio (DER) (X2) in the amount of 0.627767 for PT. Astra Auto Part Tbk in 2012.

The maximum in the amount of 302,864407 for PT. Multi Bintang Indonesia Tbk in 2014. The average value is 67.05732559 and the standard deviation value is 51.709497905 .

The variable X3 is Return On Assets (ROA). From this study the minimum value of X3 is 0.130000 for PT. Astra Auto Part Tbk in 2012. The maximum value in the amount of 
66.909089 for PT. Multi Bintang Indonesia Tbk in 2012. The average value of this X3 variable is 15.12431608 and the standard deviation value is 11.316392045 .

Y variable is Dividend Payout Ratio (DPR). From this study the minimum Y value is 0.397727 for PT. Astra Auto Part Tbk in 2012. The maximum value of this $\mathrm{Y}$ variable is 126,315790 for PT. Arwana Citra Mulia Tbk in 2015. The average value is 42.35015256 and the standard deviation value obtained is 27.811057454 .

The opinion of Ghozali (2013) as the same as Priyatno (2013) as one of the requirements to conduct a regression test is that the data used must have normal or near-normal data distribution. To perform normality testing, one - sample Kolmogorov-smirnov test was used with a significance level of $>0.05$ using the SPSS program (8)

Multicollinearity test aims to test whether the regression model found a correlation between independent variables (dependent). A good regression model does not have a correlation between independent variables. The common cut-off value used to indicate multicollinearity is the tolerance value of $\leq 0.10$ or VIF value $\geq 10$. So in this study the regression model does not occur multicollinearity.

According to Ghozali (2013) the autocorrelation test aims to test whether in the linear regression model there is a correlation between the interfering errors in the previous period. If there is a correlation, then there is an autocorrelation problem. The Durbin-Watson value in this regression is 1.448 , the Durbin-Watson value is between -2 to +2 , this means there are no negative or positive autocorrelations in this regression model (8)

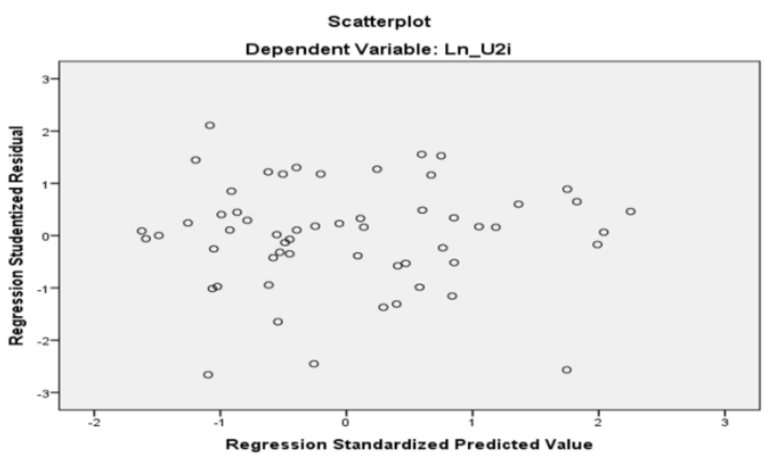

Fig. 1. The result of SPSS calculation

Heteroscedasticity test aims to test whether the regression model occurs from residual variance to one observation to another observation. If the residual variance from one observation to another observation remains, it is called homoskedasticity and if it is different it is called heteroscedasticity. A good regression model is that homoskedasticity or heteroscedasticity does not occur. Using a scatterplot graph is said to occur or not heteroscedasticity with a significant value above the confidence level of $5 \%$ or 0.05 .

The coefficient of determination (R2) according to Ghozali (2013) aims to measure how far the ability of the model in explaining the variation of the dependent variable. 


Model Summary
\begin{tabular}{|l|l|l|l|l|l|}
\hline Model & R & R Square & $\begin{array}{l}\text { Adjusted } \\
\text { Square }\end{array}$ & $\begin{array}{l}\text { Std. Error of } \\
\text { the Estimate }\end{array}$ & $\begin{array}{l}\text { Wurbin- } \\
\text { Watson }\end{array}$ \\
\hline 1 & $388^{\mathrm{a}}$ & 150 & 128 & 25,964585895 & 1,448 \\
\hline
\end{tabular}
a. Predictors: (Constant), ROA, Cash Ratio, DER
b. Dependent Variable: DPR

Fig. 2. The result of SPSS calculation

The amount of adjusted R2 is 0.128 or $12.8 \%$, this indicates that the ability to explain the independent variables namely Cash Ratio, Debt to Equity Ratio (DER) and Return On Assets (ROA) to the dependent variable is $12.8 \%$. While the remaining $87.2 \%$ is explained by other factors outside of this regression model (8).

According to Ghozali (2013) the F statistical test basically aims to show whether all the independent variables or independent variables included in the model have a joint effect on the dependent variable or dependent variable (8).

\begin{tabular}{|c|c|c|c|c|c|c|}
\hline \multicolumn{7}{|c|}{ ANOVA $^{\mathrm{a}}$} \\
\hline$\overline{\mathrm{Mo}}$ & & $\begin{array}{ll}\text { Sum of } \\
\text { Squares }\end{array}$ & Df & $\begin{array}{l}\text { Mean } \\
\text { Square }\end{array}$ & $\bar{F}$ & Sig. \\
\hline \multirow{3}{*}{1} & Regression & 13838,607 & 3 & 4612,869 & 6,842 &, $000^{b}$ \\
\hline & Residual & 78202,528 & 116 & 674,160 & & \\
\hline & Total & 92041,135 & 119 & & & \\
\hline
\end{tabular}

Fig. 3. The result of SPSS calculation

The $\mathrm{F}$ value is 6.842 with a probability of 0.000 and is still much smaller than the significant rate of 0.05 or $5 \%$, it can be stated that the model of this study is stated to be fit a) $\mathrm{H} 1$ : Effect of cash ratio on Dividend Payout Ratio (DPR) based on $\mathrm{t}$ test.

\begin{tabular}{|c|c|c|c|c|c|c|}
\hline \multicolumn{7}{|c|}{ Coefficients $^{\mathrm{a}}$} \\
\hline \multirow[t]{2}{*}{ Mod } & & \multicolumn{2}{|c|}{ Unstandardized Coefficients } & \multirow{2}{*}{\begin{tabular}{|l|}
$\begin{array}{l}\text { Standardized } \\
\text { Coefficients }\end{array}$ \\
Beta
\end{tabular}} & \multirow[t]{2}{*}{$\mathrm{T}$} & \multirow[t]{2}{*}{ Sig. } \\
\hline & & B & Std. Error & & & \\
\hline \multirow{4}{*}{1} & (Constant) & 23,714 & 5,730 & & 4,138 & 0,000 \\
\hline & Cash Ratio &, 010 & .025 & .041 & ,415 & ,679 \\
\hline & DER &, 125 & ,057 &, 232 & 2,193 &, 030 \\
\hline & ROA &, 617 & 228 & .251 & 2,702 &, 008 \\
\hline
\end{tabular}

Fig. 4. The result of SPSS calculation

The results of the test can be seen from the results of the partial test $(\mathrm{t})$ showing the $\mathrm{t}$ value of the cash ratio of 0.415 with a significance value of $0.679>0.05$ or $5 \%$. This means that the cash ratio does not affect the Dividend Payout Ratio (DPR) variable because it is greater than the significance value of 0.05 .

The results of this test are consistent with the tests conducted by Swastyastu, et al (2014) which examine the analysis of factors that influence the Dividend Payout Ratio (DPR) policy 
listed on the Indonesia Stock Exchange (IDX). The sample of this study is all companies listed on the capital market in the specified period. The results showed that the cash ratio did not affect the Dividend Payout Ratio (DPR) listed on the Indonesia Stock Exchange (IDX). Where the cash ratio has a value of $t$ count of -1.016 and a probability value of 0.315 is greater than the significant 0.05 (9).

Cash ratio or $\mathrm{H} 1$ in the research hypothesis which states that the influential cash ratio on the Dividend Payout Ratio (DPR) is rejected. From the results of the study be concluded that the cash ratio position is not too strong to calculate dividend payments where cash which is owned the company is calculated to pay the company's short-term debt. Thus HO is accepted and $\mathrm{Ha}$ is rejected.

b) H2 : Effect of Debt to Equity Ratio (DER) on Dividend Payout Ratio (DPR) based on ttest.

Based on the value of t test, Debt to Equity Ratio (DER) of 2.193 with a significant value of $0.030<0.05$, it can be concluded that the variable Debt to Equity Ratio (DER) has a partial effect on the Dividend Payout Ratio (DPR).

The results of this study are consistent with the research conducted by Liza Tania (2014). The research shows that the Debt to Equity Ratio (DER) affects the Dividend Payout Ratio (DPR) of companies listed on the Indonesia Stock Exchange (IDX) (10).

The company's commitment in the manufacturing sector to make regular dividend payments causes the company's ability to pay dividends not to be affected by the size of the company's debt and even the increase in debt can increase the company's ability to pay dividends during the use of debt accompanied by increased corporate profits. This is in accordance with the financial theory that states do not make new debt if the company cannot generate additional profits (Riyanto, 2008). Thus $\mathrm{H} 2$ this study states that the variable Debt to Equity Ratio (DER) has an effect on the Dividend Payout Ratio (DPR) received. Thus H0 is accepted and $\mathrm{Ha}$ is rejected. test.

c) H3 : Effect of Return On Assets (ROA) on Dividend Payout Ratio (DPR) based on t-

Based on the statistical test $t$ the value of $t$ calculated Return On Assets (ROA) is 2.702 with a significance value obtained at $0.008<0.05$ or $5 \%$. This means that Return On Assets (ROA) has a partial and significant effect on the Dividend Payout Ratio (DPR).

Consistent with the research conducted by Liza Tania (2014) on the analysis of the effect of cash position, Debt to Equity Ratio, Return on Assets (ROA), cash ratio, assets growth, and firm size on the Dividend Payout Ratio (DPR) which states that Return On Assets (ROA) has a positive and significant influence on the Dividend Payout Ratio (DPR) variable. Based on the results, it shows that Return On Assets (ROA) shows the number 1.690 with a significant level of $0.000<0.05(10)$.

Therefore H3 which states that Return On Assets (ROA) has a positive and significant effect on the Dividend Payout Ratio (DPR) received. The greater Return On Assets (ROA) means to show a good company performance, because the level of return on investment is getting bigger. Increasing Return On Assets (ROA) will also increase dividend income. Thus $\mathrm{Ha}$ is accepted and $\mathrm{HO}$ is rejected. 


\section{Conclusion and Suggestion}

\section{Conclusion :}

1) Cash ratio does not affect the Dividend Payout Ratio (DPR).

2) Debt to Equity Ratio (DER) has a significant effect on the Dividend Payout Ratio (DPR).

3) Return On Assets (ROA) has a significant effect on the Dividend Payout Ratio (DPR).

Suggestion :

1) Future research are expected to take samples in longer observation periods or use more up to date periods.

2) Future research is expected not only to research companies that are listed on the Indonesia Stock Exchange (IDX) but also on a wider scale.

3) Future research is expected to add several other variables outside of this research.

\section{References}

1. Darma FA, Segoro W. PENGARUH LEVERAGE, PROFITABILITAS, LIKUIDITAS DAN GROWTH TERHADAP KEBIJAKAN DIVIDEN PERUSAHAAN NONBANK LQ-45. In: Seminar Nasional Dies Natalis UNS XXXVIII. 2014.

2. Gumanti TA. Kebijakan Dividen Teori, Empiris dan Implikasi. 2013.

3. MAHARDIKA, Fajar, Wahyudi S, Mawardi W. PENGARUH CASH RATIO, DEBT TO EQUITY RATIO, PROFITABILITY DAN SALES GROWTH TERHADAP DIVIDEND PAYOUT RATIO DAN DAMPAKNYA PADA NILAI PERUSAHAAN (Studi Empirik pada Perusahaan Manufaktur yang Terdaftar di Bursa Efek Indonesia tahun 2010-2014). 2016.

4. Minanari M. Pengaruh Profitabilitas, Manajemen Laba dan Kebijakan Deviden terhadap Nilai Perusahaan (Studi Empiris pada Perusahaan Manufaktur yang Terdaftar di Bursa Efek Indonesia Periode 2015-2016). 2016.

5. Nurhayati M. Profitabilitas, likuiditas dan ukuran perusahaan pengaruhnya terhadap kebijakan dividen dan nilai perusahaan sektor non jasa. J Keuang Bisnis Progr Stud Magister Manaj Sekol Tinggi Ilmu Ekon Harapan. 2013;144-53.

6. Hasibuan M. Pengaruh Cash Ratio, Debt to Equity Ratio, Return On Assets Terhadap Kebijakan Dividen Payout Ratio Pada Perusahaan Manufaktur Yang Terdaftar Di Bursa Efek Indonesia Periode 2005-2009. 2012;

7. Sari MR, Andini R. PENGARUH PERTUMBUHAN PERUSAHAAN, UKURAN PERUSAHAAN, EARNING PER SHARE, CURRENT RATIO, RETURN ON EQUITY DAN DEBT EQUITY RATIO TERHADAP KEBIJAKAN DIVIDEN (Studi Pada Perusahaan Manufaktur di BEI Tahun 2011-2014). J Account. 2016;2(2).

8. Ghozali I. Aplikasi analisis multivariate dengan program SPSS. 2006.

9. Swastyastu, Made Wiradharma et al. Analisis Faktor-Faktor yang Mempengaruhi Kebijakan Dividend Payout Ratio yang Terdaftar di Bursa Efek Indonesia (BEI). J Ilm 
Mhs Akunt. 2014;Undiksha 2.

10. Tania, Liza. Analisis Pengaruh Cash Position." Debt To Equity Ratio (DER), Retrun On Asset (ROA), Cash Ratio, Asset Growth, dan Firm Size terhadap Dividen Payout Ratio (Studi Pada Perusahaan m manufaktur yang terdaftar di BEI Periode 2009. 2012). Jur Manaj dan Bisnis Fak Ekon Univ Dian Nuswantoro. 2013; 